\begin{tabular}{|c|c|}
\hline 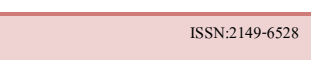 & \\
\hline $\begin{array}{c}\text { TOURISM } \\
\text { AND } \\
\text { MANAGEMENT }\end{array}$ & $\begin{array}{l}\text { Journal of Tourism\&Management Research } \\
\text { ISSN: } 2149-6528 \\
2020 \text { Vol. 5, Issue.1 }\end{array}$ \\
\hline AN INTERATIONAL JOURNAL & \\
\hline
\end{tabular}

\title{
The Perception of Residents of Akure Metropolis on Green Environment
}

\begin{abstract}
Green space has an important positive effect on people's lives, one of the major effects is air purification which helps to reduce a lot of airborne disease contributing to resident health positively. The study, therefore, assessed perceived influences of green spaces on environmental, health and aesthetic beauty of Akure metropolis. Specifically, the study examined the perception, familiarity and attitude of residents towards green space. Certain metropolitan locations were randomly selected in Akure in order to design 150 questionnaires. Respondents were randomly selected from these locations with wellstructured interview schedule and questionnaire administration. Data collected was analyzed using descriptive and inferential statistics. The study revealed information on the demographic characteristics of the respondents and asserted that keeping green space has contributed to health improvement, ecological, social and economic wellbeing of the inhabitants. There is significant relationship between level of education and the propensity to keeping green space. Hence, there is need to intensify awareness on the benefits accrued for keeping green space in Akure Metropolis
\end{abstract}

Keyword: Aesthetic beauty, green space, health improvement, metropolitan locations, populations

JEL Codes: D1, R11, Z32

Submitted: 18/01/2020; Accepted: 23/04/2020

Oladeji Sunday Oladipo, Lecturer. (Corresponding author). Department of Ecotourism and Wildlife, Management. Federal University of Technology, Akure, Ondo-State. Nigeria.

Telephone: +2348030698896. Email: sooladeji@futa.edu.ng; oladejisunny@yahoo.com

Obe Kehinde Rebecca, Lecturer. Department of Ecotourism and Wildlife, Management. Federal University of Technology, Akure, Ondo State. Nigeria. Telephone: +2347033990250

Email: obekennyd@gmail.com

Alabi Opeyemi lyin Oluwa, Lecturer. School of Applied Science and Technology, Department of Hotel Management, Federal Polytechnic Auchi. Nigeria.

Telephone; +2348030698896. Email: iyinoluwaopeyemi@gmail.com 


\section{Introduction}

World Health Organization (WHO, 2016) reported that green space is a piece of land occupied with trees, grasses, shrubs in yards, parks, medians and anywhere intermixed throughout the built environment. Green space can, therefore, be regarded as an area of land developed as parks, golf courses, sports fields and other recreational purposes within the built-up area. The need for urban residents to know green environment/space through attitudinal change towards the environment and the provision of green products has been emphasised (Tan \& Lau, 2010). This assertion was based on the recorded benefits of green space to man and the environment, some of which include; water quality protection reduced heat build-up, reduced soil erosion, improved air quality, natural resource conservation, support green tourism and many more. Determining what people know about the environment, how they feel about it, and what actions they take may help or harm the environment is critical in establishing the sustainability of a community. Considerate in this direction will create a strong national environmental movement that will conserve the environment through solving environmental problems (Sudarmadi et al., 2001).

Depletion of green space because of land-use change has been reported in 25 European countries, this has resulted in losses of green space between 7.3 and 41 percent (European Environment Agency (EEA, 2002). A study conducted on land-use change in 274 metropolitan areas in the USA revealed a loss of about 1.4 million hectares of green spaces to different land developments (McDonald et al., 2010). However, the situation is worse in Africa countries where gradual degradation of natural resources, extensive pollution, and ineffectiveness of technical solutions used to resolve diverse environmental challenges have been reported in developing countries like Ghana (Amoako \& Korboe, 2011; Hopkins et al., 2001; Ministry of State for Environmental Affairs, 2005). For instance, studies in different African cities (Fuwape \& Onyekwelu, 2011, MaConnachie et al., 2008; Makworo \& Mireri, 2011; Mpofu, 2013; Oduwaye, 2013) found massive depletion of urban green spaces with attendance low coverage of green spaces in the landmass of many African cities (often they cover less than 10 percent of the total land area). At the moment, the rapid depletion of green spaces in Africa has resulted in green spaces occupying small percent of the total land space of many urban areas. For example, it has been discovered that several towns in the Republic of South Africa have less than 10 percent of their total lands occupied by green spaces (MaConnachie et al., 2008). Oduwaye (2013) observed that the situation in Lagos city (Nigeria) is more alarming, green spaces now occupy less than 3 percent of the city's landmass. Other studies focusing on developing countries produced comparable results with urban green spaces found to be depleting at an alarming rate (Gomes \& Moretto, 2011; Yusof, 2012). Kumasi City in Ghana once regarded as Garden city of West Africa, have been depleted remaining only a small fraction which with other open spaces constitute about 10.7 percent of the total land area of Kumasi (Amoako \& Korboe, 2011).

Despite the excessive destruction and poor management of green spaces in many regions of the world and Africa studies on urban green spaces with particular emphasis on uncovering the challenges confronting green spaces are less focused in Africa. Several reasons can be adjudged for the negligence and lack of attention on the protection and conservation of green space in Africa. Bolnick et al. (2006) and Marcotullio (2001) highlighted that pressures are engulfing many Africa nations in addressing poverty, health, and sanitation problems and providing basic human needs. The authors stressed that all these have constituted the priorities of many developing countries with little or no attention towards the protection of green space The associated problems with decreasing green space call for much attention to be made to protect urban green spaces in developing countries so the benefits attached to these spaces can easily be tapped. There is therefore urgent need to bridge knowledge gaps in the literature on urban green spaces in Africa through the development of mitigation approaches to ensure preservation and protection of the environment. 
Lizuka (2000) opined that the recent changes in sources of environmental problems have called for change in the attitude of the people. The author went further to assert that the sources of environmental problems such as pollution have shifted from production to consumption processes hence, attitudinal change is appropriate approach. This supports the findings of the Human Development Report of 1998 United Nation Development Programme (UNDP) that countries that reported growth in consumption and unbalanced consumption patterns are pressuring the environment through their consumption pattern. Current research should focus on studies of human perception, attitude and pro-environmental behaviour in the public, with the view to gather much-needed support to adopt a sustainable lifestyle in protecting the environment. Suffice to say that anthropogenic activities because of urbanization and increasing population are leading to drastic and alarming exploitation of nature and resultant unhealthy ecology in urban areas. Metropolitans in many developing countries are experiencing environmental glitches such as deterioration of air quality, higher air temperature, increasing noise levels, greater psychological stress and deteriorating social status of community (Gomes \& Moretto, 2011; Yusof, 2012). All these explain the significance of urban green spaces in improving the microclimate and addressing diverse social and ecological challenges confronting urban areas. Miyan and Rakibul (2003) concluded that the effects of lack of green space couple with the exponential population increase in the twentieth century to include aggravating physical, social, psychological and environmental hazards, especially in the third world countries.

Against this backdrop, this study looks closely at the numerous contributions that urban green spaces offer to the overall growth of cities, to justify the need to preserve these spaces in the urban physical landscape. The research, therefore, focuses on assessing the green space in Akure Metropolis with emphasis on attitudinal change vis-à-vis the consciousness and the perception of people towards green environment rather than production. The aim of the study is, therefore, to provide information about urban residents' perception towards their environment adding to the knowledge base on the literature on urban residents and perception toward the green environment.

\section{Literature Review}

\subsection{Benefits of Green Space}

Human desire for greenery is often expressed as appreciation of the social, economic and other advantages and an urge to connect with nature (Miller, 1997). Green space has a lot of benefit social, economic, cultural, environmental and health benefits. Preserving natural environment such as green spaces in the physical landscape of urban areas has been identified to enhance the health and well-being of urban dwellers (Cohen et al., 2008; Wolch et al., 2014). Promoting green tourism is also one of the numerous benefits of maintaining green space, it guarantees sustainability in the sense that it ensures the needs of the present generations are meet without jeopardizing the ability of the future generation in meeting these needs. This forms part of the view of Fandeli (2000), that green tourism is a form of ecotourism that was promoted by the organization of the ecotourism society in 1990 involving travel to natural areas to conserve the environment and preserve the life and well-being of local residents.

\subsection{Environmental Value of Green Spaces}

The numerous environmental values of green space have been discussed by authors in the literature (Baycan-Levent \& Nijkamp, 2005a; Ernstson, 2012; Jennings et al., 2012). For instance, Jennings et al. (2012) opined that trees and other green space support the growth of urban areas through improving urban air quality and ameliorating the microclimate. Addressing mental and psychological disorders, preserving biodiversity, promoting ecotourism, providing employment opportunities, beautifying architectural designs of cities 
and supporting social interaction and cohesion (Fam et al., 2008). A study focusing on Ottawa and Singapore, where most of the buildings have green vegetation on their roofs, showed considerable reduction of sulphur dioxide and nitrous oxide in those areas (Getter \& Rowe, 2006). The availability of many urban trees has been observed to enhance urban air quality by helping to remove some pollutants such as carbon monoxide, nitrogen oxide and sulphur dioxide from the atmosphere (Nowak et al., 2006). This shows that the presence of many urban trees (green spaces) helps to intercept the movement of some pollutants and consequently minimize the rate of urban air pollution. There are indications that presence of open green space can reduce noise pollution in our urban areas caused mostly by visual intrusion from traffic, although more specific evidence on how this should be done in order to inform better design guidance could be useful. Manlun (2003) on the other hand perceived environmental value of urban green space from architectural perspective. The author affirmed that urban green spaces help to beautify urban design and the overall urban landscape. The author (2003) went further to express that green spaces improves aesthetic value of urban architecture thereby creates uniformity and diversity in urban areas. This assertion is line with the views of Baycan-Levent and Nijkamp (2005a) that in designing towns and cities, green spaces are very important because they help to enhance their identity which can improve the cities' attractiveness as places to live, work, invest in and as tourist destinations. Taking the various environmental contributions of green spaces into account, it can be deduced that these contributions help to address various urban environmental problems affecting both developed and developing countries.

\subsection{Health and Wellbeing Value of Green Space}

The contribution of green space in improving the health and wellbeing of urban dwellers cannot be over emphasised (Barton \& Pretty, 2010; Ernstson, 2012; Maas et al., 2009). Lafortezza et al. (2009) highlighted the importance of green space in alleviating stress while Louv (2005) and Faber et al. (2001) stressed the value of green space in correcting mental disorders in children such as Attention Deficit Hyperactivity Disorder. The use of urban green spaces for physical activities such as walking, jogging, playing football and other sporting activities has been found to help address the problem of obesity and prevent diseases such as cardiovascular disease, musculoskeletal diseases, stroke and cancer (World Health Organisation, 2007). Studies on the elderly in northern England, Tokyo and some megacities in the world have revealed that the usage of parks by the elderly for physical activities helps to keep them fit, relieves them of some chronic diseases associated with old age and enhances their lifespan in general (Milligan et al., 2004; Takano et al., 2002). There is evidence that environmental exposures relate to incidence of lung cancer (Pope et al., 2002). The intricate link between exposure to green space and improving the wellbeing of the local community has been documented by Kim and Kaplan (2004). The authors indicated that green spaces and other natural features play an important role in attaching and connecting people to the area in which they live and their local community at large.

\subsection{Social, Cultural and Economic Values of Green Spaces}

Urban green spaces contribute significantly to the preservation and conservation of National heritage and culture. The contribution of Urban Green Space for improving residents' satisfaction, enhancing urban life and increasing the number of areas available for hosting event such as national and local ceremonies like cultural festivals, wedding engagements has been reported by the National Audit Office (NAO, 2006). In addition to this, urban green spaces serve as collection hub of tangible heritage resources that are ancient, historic and cultural artefacts (Dümcke \& Gnedovsky, 2013). NAO (2006) further discoursed that there is need for local government to approach the development and planning of urban squares, parks, corridors and green space in such a manner that it will lead to improvement in the quality of 
life, ameliorate the microclimate, provide natural air conditioning and exotic pavilions which help to preserve culture and national heritage of a community. In view of the aforementioned, it could be declared that green spaces offer a range of social and economic contributions as rendezvous for leisure and recreation, children playground, football pitch and other social engagement in urban areas in both developed and developing countries. People engage in the sales of foods, drinks and other goods in green spaces that serve as recreation and other social opportunities. This serve as source of employment and means of generating income for the people. Generation of income for local residents in form of sales of agricultural product from garden in the yards and small-scale farming from green space such as sales of horticulture, fruits, vegetables, herbs, cash crops, by some residents has been reported in literatures (Bedimo-Rung et al., 2005, Galhena et al., 2013).

\subsection{Biodiversity Conservation Value of Green Space}

The conservation and protection of biodiversity in urban areas are stated in the literature on biodiversity conservation (Alvey, 2006; Cornelis and Hermy, 2004; Godefroid and Koedam, 2003; Jim and Liu, 2000). Cornelis and Hermy (2004) in a survey of 15 parks in urban areas of Flanders (Belgium), observed that those parks contain about 30 percent, 50 percent and 60 percent of wild plants, birds and amphibians respectively. Similarly, Tanner and Gange (2005) revealed that golf courses in the UK have a high volume of tree species and wide diversity of birds.

\subsection{Perception on Green Space}

The resultant effects of green space on perceptions and behaviours of people has been documented (Bonnes et al., 2011; Sanesi \& Chiarello, 2006; Swanwick et al., 2003). The authors opined that decrease in urban green spaces restrict people from experiencing opportunities offer by visiting pristine areas. It was stressed that there is connection between green environment, resident life and residents' connection with nature, particularly with the availability of green spaces in their immediate surroundings. Emotional responses and people's perception of their environment have something to do with the composition of their external environment in term of understanding places, spaces and their uses. Schiffman and Kanuk (1987) have observed that perception means to become aware of something using external clues, or the process through which individuals see the world around them. Bonnes et al. (2011) contend that the exploration of green space, place and perception provides insights into human-nature integration. Hence, the importance of understanding place-specific experience in urban green areas through self-reported perception of use and quality of such space cannot be ignored.

\section{Methodology}

\subsection{Sampling and Data collection}

For the achievement of the aim in undertaking this study, both primary and secondary data sources were collected to support the findings. The secondary data on the residential districts and population census in Akure metropolis was procured from the Akure South Local Government Area (AKSLGA) office. The population census obtained for the year 2006 $(484,798)$ was later projected to $2018(637,456)$. The residential districts in the metropolis were later categorized based on the standard of living of the residents into high, middle, and low (see Table 1). Sample locations for the primary data was chosen to use convenience sampling representing four (4) out of the twelve (12) categories of locations while the sample size was determined based on value using Krejcie \& Morgan table for a known population. While 450 structured questionnaires were administered, 431 questionnaires correctly completed were recovered and descriptively analysed, representing $95.77 \%$ response rate. The data collected was analysed using the Statistical Package for Social Sciences (SPSS) SPSS 
Data editor version 22.0 software and presented descriptively in form of percentage in tables. Regarding the perceptions of the respondents on green space, variables on the benefits of green space have been divided into 8 categories such as contribution to aesthetic beauty, health improvement and fitness, environmental protection, biodiversity conservation, economic livelihood of the local people etc. Likewise, approach that can be adopted in promoting green space were divided into various variable including sharing benefits to educate family and friends, advocate for green space etc. Closed-ended questionnaires using 5-point Likert scale were distributed to respondents in order to comprehend their perceptions on green space (Tewari, 2019) and 3-point Likert scale was used in order to understand the approach that can be adopted in promoting green space.

Weighted mean scores were computed and the upper limit of data about the perception on green space is 4.5-5.0 and the lower limit score is $<1.5$, while the upper limit of data about approach that can be adopted is 2.5-3.0 and the lower limit score <1.5. The decisions were taken based on the value obtained on weighted mean score:

Weighted Mean $($ WM $)=$ Sum of Weighted Frequencies/Sum of Initial Frequencies

Weighted mean $(W M)=\Sigma w \boldsymbol{x} / \Sigma \boldsymbol{w}$

Where $\Sigma=$ the sum of., $\boldsymbol{w}=$ the weights, $\boldsymbol{x}=$ the value.

Weighted Mean $=w 1 \times 1+w 2 \times 2+\ldots+w n x n \div w 1+w 2+\ldots+w n$

Decision rule:

Respondent perception on green space: Strongly agree $=4.5-5.0$, Agree $=3.5-4.4$, Undecided $=2.5-3.4$, Disagree $=1.5-2.4$, strongly disagree $=<1.5$.

Respondent about the approach that can be adopted: will do it $=2.5-3.4$, undecided $=1.5$ -

2.4, will not do $=\leq 1.5$.

Table 1: Categories of metropolitan places in Akure.

\begin{tabular}{|c|c|c|c|}
\hline Categories & High-level & Middle-level & Low-level \\
\hline \multirow{4}{*}{ Places } & Ijapo & Oda road & Oke aro \\
\hline & Futa south & Oba Adeshida & Fanibi \\
\hline & Orita obele & Ajipowo & Itaoniyan \\
\hline & Alagbaka & Awule & Gaga \\
\hline
\end{tabular}

\section{Results}

\subsection{Descriptive Statistics}

This study revealed information on the demographic characteristics of the respondents (Table 2). Female constituted the highest percentage (54.3\%) while those in the age range of 15-24 years have the maximum percentage $(55.5 \%)$ and the majority of them attained tertiary education $(49.4 \%)$ 
Table 2: Socio demographic information of the respondent administered questionnaire.

\begin{tabular}{|c|c|c|}
\hline Demographic information & Frequency & Percentage $(\%)$ \\
\hline \multicolumn{3}{|l|}{ Gender } \\
\hline Male & 197 & 45.7 \\
\hline Female & 234 & 54.3 \\
\hline \multicolumn{3}{|l|}{ Age (years) } \\
\hline $0-15$ & 0 & 0 \\
\hline $15-24$ & 239 & 55.5 \\
\hline $25-54$ & 137 & 31.8 \\
\hline $55-64$ & 51 & 11.8 \\
\hline 64 and above & 4 & 00.9 \\
\hline \multicolumn{3}{|l|}{ Level of Education } \\
\hline Primary & 21 & 4.9 \\
\hline Secondary & 192 & 44.5 \\
\hline Tertiary & 213 & 49.4 \\
\hline No formal education & 5 & 1.2 \\
\hline
\end{tabular}

Source: Field Survey, 2018.

As shown in table 1, from the weighted mean score of 4.43 and applying the decision rule, it could be affirmed that the respondents strongly agreed that green space contributes to the aesthetic beauty. This was followed by the weighted mean score value of 4.42 and ended with a conclusion that green space is important in environmental protection. Besides that it could be deduced that respondents agree that keeping green space improve their economic livelihood (4.17) (see Table 2).

Table 2: Perception of the respondent on the benefit of green space.

\begin{tabular}{|l|c|c|c|c|c|c|c|c|}
\hline Variable & SD & D & U & A & SA & $\begin{array}{c}\text { Weighted } \\
\text { Sum }\end{array}$ & $\begin{array}{c}\text { Weighted } \\
\text { Mean }\end{array}$ & Decision \\
\hline $\begin{array}{l}\text { It contributes to aesthetic } \\
\text { beauty }\end{array}$ & 16 & 13 & 8 & 128 & 266 & 1908 & 4.43 & SA \\
\hline $\begin{array}{l}\text { It contributes to health } \\
\text { improvement and fitness }\end{array}$ & 23 & 13 & 24 & 88 & 283 & 1888 & 4.38 & A \\
\hline $\begin{array}{l}\text { It contributes to environmental } \\
\text { protection }\end{array}$ & 18 & 10 & 21 & 108 & 274 & 1903 & 4.42 & SA \\
\hline $\begin{array}{l}\text { It contributes to biodiversity } \\
\text { conservation }\end{array}$ & 24 & 45 & 26 & 134 & 201 & 1733 & 4.02 & A \\
\hline $\begin{array}{l}\text { It contributes to economic } \\
\text { livelihood of local people }\end{array}$ & 19 & 26 & 21 & 163 & 202 & 1796 & 4.17 & A \\
\hline $\begin{array}{l}\text { It contributes positive impact } \\
\text { on the ecosystem }\end{array}$ & 14 & 22 & 26 & 107 & 262 & 1874 & 4.35 & $\mathrm{~A}$ \\
\hline $\begin{array}{l}\text { It serves as habitat for } \\
\text { dangerous animals }\end{array}$ & 147 & 59 & 59 & 73 & 93 & 1199 & 2.78 & $\mathrm{U}$ \\
\hline \begin{tabular}{l} 
It contributes to land wastage \\
\hline
\end{tabular} & 244 & 64 & 33 & 33 & 57 & 888 & 2.06 & $\mathrm{D}$ \\
\hline
\end{tabular}

Source: field survey 2018. 
As shown in table 3, the respondent likely attitude that can promote green space revealed the respondents are ready to sharing knowledge to educate their neighbour, family and friends on the benefit of green space with score of 2.65 as the highest weighted mean score while lowest weighted mean value represents those were undecided on attending city council meetings that deals with city planning, public transportation, and energy, air and water quality to learn more (2.47) (Table 3).

Table 3: Approaches that can be adopted to promote green space.

\begin{tabular}{|l|c|c|c|c|c|c|}
\hline Variable & Will not do it & Undecided & Will do it & $\begin{array}{c}\text { Weighted } \\
\text { Sum }\end{array}$ & $\begin{array}{c}\text { Weighted } \\
\text { Mean }\end{array}$ & Decision \\
\hline $\begin{array}{l}\text { Sharing knowledge } \\
\text { to educate family and } \\
\text { friend on the benefit } \\
\text { of green space }\end{array}$ & 32 & 29 & 350 & 1140 & 2.65 & Will do it \\
\hline $\begin{array}{l}\text { Advocate for more } \\
\text { public green space }\end{array}$ & 35 & 121 & 275 & 1102 & 2.56 & Will do it \\
\hline $\begin{array}{l}\text { Attend city council } \\
\text { meetings that deal } \\
\text { with city planning } \\
\text { public transportation } \\
\text { energy, air and water } \\
\text { quality to learn more }\end{array}$ & 43 & 138 & 249 & 1066 & 2.47 & Undecided \\
\hline $\begin{array}{l}\text { Promote sustainable } \\
\text { environmentally } \\
\text { beneficial landscape } \\
\text { practice in Akure } \\
\text { metropolis }\end{array}$ & 40 & 121 & 270 & 1092 & 2.53 & Will do it \\
\hline $\begin{array}{l}\text { Implement more } \\
\text { regulation and } \\
\text { changes in city } \\
\text { planning that } \\
\text { incorporate more } \\
\text { green space and } \\
\text { natural environment } \\
\text { into design }\end{array}$ & 38 & 130 & 263 & 1087 & 2.52 & Will do it \\
\hline
\end{tabular}

Source: field survey 2018.

\section{Conclusion, Implications and Limitations}

The study has shown that most of the respondents are well learned young adults mostly female in their active age range that are knowledgeable of the benefits of green space. This agrees with the findings of Ewulo et al. (2015) that greater percentage of inhabitants of Akure metropolis possessed tertiary education. Seemingly, this is in tandem with the previous research by (Kruize et al., 2019) that the higher the level of literacy, the better the perception of populace towards acculturation of green space.

Furthermore, Miyan and Rakibul (2003) opined that the higher the level of education the higher the positive perceptions about the values of green space in environmental development of urban area. Gender differences in agriculture and land use planning have been regarded as basis for development of gender sensitive policies that dismantles every form of discrimination against women (Edinyang \& Angiating, 2018). This forms part of the approaches that can be adopted for promoting green space as indicated by the respondents that there is need to implement more regulation and changes in city planning that incorporate more green space and natural environment into design. Their perception towards the positive 
contributions (Health, aesthetic beauty, economic livelihood of the residents) of green space in their environment is highly positive. It is widely understood that urban green spaces improve the physical, economic and psychological well-being of its dwellers (Lachowycz \& Jones, 2011; Lee \& Maheswaran, 2010, WHO, 2017). Also, Oladeji and Adedapo (2014) observed that highest proportion of visitors to Ministry of Agriculture Botanical Garden, Oyemekun Rock and T.A. Afolayan Park in Akure Metropolis are for relaxation, sightseeing in apprecistion of the senery and aesthetic beauty. These contributions stem from close contact with green spaces to improving mental health and psychological well-being (Barton \& Pretty, 2010; Ernstson, 2012; Maas et al., 2009).

Following the trends in this research, the perception of the respondents on the contributions of green space to biodiversity is in line with previous research on the study of urban environment which shown that different forms of urban green spaces contain significant biodiversity (Alvey, 2006; Bonnes et al., 2011; Cornelis and Hermy, 2004; Godefroid and Koedam, 2003; Jim and Liu, 2001). More so, the respondents are undecided that green space serves as reserve or habitat for harmful animals. But there is the tendency for an increased revolution for a green environment because of the high positive response towards promotion of more green spaces in their environment.

Arising from the findings of this study, there is need to sustain the increasing level of awareness on the benefit of keeping green in Akure metropolis. Appropriate planning should be put in place in the course of developing built environment within urban metropolis in such a way that the green space is preserved and not negatively impacted because of its economic, aesthetic and social values in urban areas. On the whole, the sample size for the study is considered small and the convenience sampling technique adopted is a type of nonprobability sampling method where the sample is taken from a group of people easy to contact or to reach generalized for whole set of population. These are considered as limitations for this study, there is therefore a need for further researchers taken into consideration large sample size across the whole area of the metropolis.

\section{References}

Alvey, A. A. (2006). Promoting and preserving biodiversity in the Urban forest. Urban Forestry and Urban Greening. 5(4), pp 195-201.

Amoako, C., and Korboe, D., (2011). Historical development, population growth and present structure of Kumasi. In: Adarkwa, A. A. (edi), Future of the tree: Towards growth and development of Kumasi. Kumasi: University Printing Press. pp. 35-54.

Barton, J. and Pretty, J. (2010). What is the best dose of nature and green exercise for improving mental health? A multi-study analysis. Environmental Science \& Technology 2010 (44), pp. 3947-3955.

Baycan-Levent, T. and Nijkamp, P. (2005a). Evaluation of Urban Green Spaces', in D. Miller and D. Patassini (eds) Beyond Benefit Cost Analysis: Accounting for Non-market Values in Planning Evaluation, pp. 63-87. Aldershot: Ashgate.

Baycan-Levent, T., Leeuwen, E., Rodenburg, C. and Nijkamp, Peter (2002). Development and management of green spaces in European cities: A comparative analysis. A paper presented at the 38th International Planning Congress on "The Pulsar Effect" planning with peaks, Gilfada. Athens, Greece.

Bedimo-Rung, A. L., Mowen, A. J. and Cohen, D.A. (2005). The significance of parks to physical activity and public health: a conceptual model. American Journal of Preventive Medicine. 28(22), pp.159-168.

Bolnick, J., Kayuni, H. M., Mabala, R., McGranahan, G., Mitlin, D., Nkhoma, S., and Donk, M. (2006). A pro-poor urban agenda for Africa: Clarifying ecological and 
development issues for poor and vulnerable population. London: International Institute for Environment and Development. 12(2), pp. 38-58

Bonnes, M., Passafaro, P. and Carrus, G. (2011). The ambivalence of attitudes toward urban green areas: between proenvironmental worldviews and daily residential experience', Environment and Behavior, 43(2), pp. 207-232.

Brauer, M. Lencar, C. Tamburic, L.; Koehoorn, M.; Demers, P. and Karr, C. A. (2008). Cohort study of traffic-related air pollution impacts on birth outcomes. Environ. Health Perspect. 116, pp.680-686.

Bussières, E.-L., Tarabulsy, G.M., Pearson, J., Tessier, R., Forest, J.-C., and Giguère, Y. (2015). Maternal prenatal stress and infant birth weight and gestational age: A metaanalysis of prospective studies. Dev. Rev. 36, pp. 179-199.

Carmona, M., Magalhaes, C. D., Blum, R., and Hopkins, J. (2004). Is the Grass Greener...? Learning from international innovations in urban green space management. London; CABE Space.

Carrus, G., Scopelliti, M., Lafortezza, R., Colangelo, G., Ferrini, F., Salbitano, F., Agrimi, M., Portoghesi, L., Semenzato, P., and Sanesi, G. (2015). Go greener, feel better? The positive effects of biodiversity on the well-being of individuals visiting urban and peri-urban green areas. Landscape Urban Plannning. 134, pp. 221-228.

Cilliers, S., Cilliers, J., Lubbe, R.; and Siebert, S., (2012). Ecosystem services of urban green spaces in African countries: Perspective and challenges. Urban Ecosystem, 16(4), pp 681-702.

Cohen, D. A., Inagami, S. and Finch, B. (2008). The built environment and collective efficacy. Health \& Place, 14(2), pp. 198-208.

Cornelis, J. and Hermy, M. (2004). Biodiversity relationships in urban and suburban parks in Flanders, Landscape and Urban Planning, 69(4), pp.385-401.

Croucher, K., Myers, L. and Bretherton, J. (2007). The links between green space and health: a critical literature review, University of York.

Dadvand, P., Sunyer, J., Basagana, X., Ballester, F., Lertxundi, A., Fernandez-Somoano, A., Estarlich, M., Garcia-Esteban, R., Mendez, M.A. and Nieuwenhuijsen, M.J. (2012). Surrounding greenness and pregnancy outcomes in four Spanish birth cohorts. Environ. Health Perspect. 120(6), pp.1481-1487.

Dunnet, N., Swanwick, C. and Wooley, H. (2002). Improving Urban Parks, Play Areas and

Open Spaces, University of Sheffield. Queen's Printer. London.

Dümcke, C. and Gnedovsky, M. (2013). The Social and Economic Value of Cultural Heritage: literature review by European Expert Network on Culture (EENC) Paper, July 2013. Retrieved April 26, 2020.

Edinyang, S. D. and Angiating, L. A. (2018): Gender discernment and the implication on Nigeria policy. Global Journal of Educational Research, 17, pp. 113-119.

Environmental Benefit of Green Space. (2008). Environmental Fact Sheet, p. 2. Retrieved May 31, 2018, from https://projectevergreen.org/resources/environmental-benefits-ofgreen-space.

Ernstson, H. (2012). The social production of ecosystem services: A framework for studying environmental justice and ecological complexity in urbanised landscapes. Landscape and Urban Planning, 109(1), pp.7-17.

European Environment Agency (EEA), (2002). Toward an urban atlas: Assessment of spatial data on 25 European cities and urban areas. Environmental Issue Rep. 30, EEA: Copenhagen.

Ewulo, T., Balogun, I.A., Okunlola, A.I. and Agele, S.O. (2015). Perception study of Trees and Greens in Open Spaces for Environmental Quality; A Case Study of Federal University of Technology, Akure. International Conference on Urban Climate jointly 
with 12th Symposium on the Urban Environment, (p. 5). Retrieved May 31, 2018, fromid2_@28cont@29-2-5631120_a.pdf.

Faber, T. A., Kuo F. E. and Sullivan W. C. (2001). Coping with ADD: the surprising connection to green play settings. Environmental Behaviour, 33, pp. 54-77.

Fam, D., Mosley, E., Lopes, A., Mathieson, L., Morison, J. and Connellan, G. (2008). Irrigation of urban green spaces: A review of the environmental, social and economic benefits. CRC for Irrigation Futures Technical Report No. 04/08.

Fandeli, C. (2000). Pengusahaan Ekowisata.Yogyakarta: Penerbit Fakultas Kehutanan Universitas Gadjah Mada .330(3), pp.13-40.

Fratini, R. and Maroni, E. (2011). Green-space in urban area: Evaluation of the efficiency of public spending for management of green urban areas, International Journal for Environmental Development 1(1), pp. 9-14.

Frumkin, H., Bratman, G.N., Breslow, S.J., Cochran, B., Kahn, P.H., Jr. Lawler, J.J., Levin, P.S., Tandon, P.S., Varanasi, U. and Wolf, K.L. (2017). Nature contact and human health: A research agenda on Environment and Health Perspective, 125.

Fuller, R.A., Irvine, K.N., Devine-Wright, R. and Gaston, K.J. (2007). Psychological benefits of greenspace increase with biodiversity. Biology Letters. 3, pp.390-394.

Fuwape, J. A. and Onyekwelu, J. C. (2011). Urban forest development in West Africa: Benefits and challenges. Journal of Biodiversity and Ecological Sciences, 1(1), pp. 7894.

Galhena, D.H., Freed, R. \& Maredia, K.M. (2013). Home gardens: a promising approach to enhance household food security and wellbeing. Agriculture \& Food Security, 2(8) pp. 112-121.

Getter, K. L. and Rowe, D. B. (2006). The role of extensive green roofs in sustainable development. Hortscience, 41(5), pp1276-1285.

Godefroid, S. and Koedam, N. (2003). How important are large vs. small forest remnants for the conservation of the woodland flora in an urban context? Global Ecology and Biogeography, 12, pp. 287-298.

Gomes, C. S and Moretto, E. M. (2011). A framework of indicators to support urban green area planning: A Brazilian case study. Proceedings of International Academy of Ecology and Environmental Sciences, 1(1), pp.47-56.

Graham, C. (1994). The Mass Media and Global Environmental Learning. Retrieved June 6, 2006, from http://www.sussex.ac.uk/units/gec/ph2summ/chapman2.htm. Green Peace International (2006). Year One of the Prestige Oil Spill: A decade of Destruction Still to Come. Retrieved August 29, 2018.

Hegaard, H.K., Pedersen, B.K., Bruun Nielsen, B. and Damm, P. (2007). Leisure time physical activity during pregnancy and impact on gestational diabetes mellitus, preeclampsia, preterm delivery and birth weight: A review. Acta Obstetricia et Gynecologica Scandinavica. 86, pp.1290-1296.

Hopkins, N. S. and Mehanna, S. R. (2000). Social Action against Everyday Pollution in Egypt. Human Organization, 59(2), pp. 245-254.

Hopkins, N. S., Mehanna, S. R. and El-Haggar, S. (2001). People and Pollution: Cultural Constructions and Social Action in Egypt. Cairo: American Universityin Cairo Press. 192(1), pp.20-26.

Irvine, K.N., Warber, S.L., Devine-Wright, P. and Gaston, K.J. (2013). Understanding urban green space as a health resource: A qualitative comparison of visit motivation and derived effects among park users in Sheffield, UK. International Journal Environmental Research Public Health. 10, pp.417-442.

Jennings, V., Johnson-Gaither, C. and Gragg, R. S. (2012). Promoting environmental justice through urban green space access: A synopsis. Environmental Justice, 5(1), pp.1-7. 
Jim, C. Y. and Liu, H.H.T. (2000). Statutory measures for the protection and enhancement of Urban forest in Guangzhou city. China Forestry.74(4), pp.311-329.

Jim, C.Y. and Chen, S. S. (2003). Comprehensive green space planning based on landscape ecology principles in compact Nanjing city, China. Landscape and Urban Planning 65(3), pp. 95-116.

Kestermont, B., Frendo, L. and Zaccaï, E. (2011). Indicators of the impacts of development on environment: A comparison of Africa and Europe. Ecological Indicators, 11, pp. 848-856.

Kim, J and Kaplan, R (2004): Physical and Psychological Factors in Sense of Community New Urbanist Kentlands and Nearby Orchard Village. Environment and Behavior 36(3), pp.313-340.

Konijnendijk, C. C., Annerstedt, M., Nielson, A. B and Maruthaveeran, S. (2013). Benefits of urban parks: A systematic review. A report to the International Federation of Parks and Recreation Administration, Copenhagen and Alnarp,70 (15), pp.1-20.

Kruize, H. , Vliet, N., Staatsen, B., Bell, R., Chiabai, A., Muiños, G., Higgins, S., Quiroga, S., Martinez-Juarez, P., Yngwe, M.A., Tsichlas, F., Karnaki, P., Lima, M.L., Jalón, S. G., Khan, M., Morris, G. and Stegeman, I. (2019). Urban Green Space: Creating a Triple Win for Environmental Sustainability, Health, and Health Equity through Behavior Change. International Journal Environmental Research Public Health 2019, 16(22), pp.4403-4421.

Lafortezza, R., Carrus, G., Sanesi, G. and Davies, C. (2009). Benefits and well-being perceived by people visiting green spaces in periods of heat stress. Urban Forestry and Urban Greening 8 (2), pp.97-108.

Louv, R. (2005). Last child in the woods: saving our children from nature-deficit disorder: $A$ Journal of Leisure Studies and Recreation Education, 21(1), pp. 136-137.

Lizuka, M. (2000). Role of environmental awareness in achieving sustainable development. Prepared for the project Enhancement of citizen's awareness in formulation of pollution control policies in major Latin American Cities, Environment and Human Settlements Division of ECLAC, with the support from the Government of Japan.

Maas, J., Verheij, R. A., des Vries, S., Spreeuwenberg, P., Schellevis, F. G. and Groenewegen P. P. (2009). Morbidity is related to a green living environment. Journal of Epidemiology and Community Health, 63, pp. 967-997.

MaConnachie, M. M., Shackleton, C. M. and McGregor, G. K. (2008). The extent of public green space and alien plant species in 10 small towns of the sub-tropical thicket biome, South Africa. Urban Forestry and Urban Greening, 7, pp.1-13.

Maes J., Barbosa A., Baranzelli C., Zulian G., Batista E Silva F. and Vandecasteele. L. (2015). More green infrastructure is required to maintain ecosystem services under current trends in land-use change in Europe. Landscape Ecology. 30, pp. 517-534.

Makworo, M. and Mireri, C. (2011). Public open spaces in Nairobi City, Kenya, under threat. Journal of Environmental Planning and Management, 54(8), pp.1107-1123.

Manlun, Y. (2003). Sustainable analysis of urban green space system based on GIS. Master's thesis submitted to the International Institute for Geo-information Science and Earth Observation, Enschede-Netherland.

Marcotullio, P. J. (2001). Asian urban sustainability in the era of globalization. Habitat International, 25, pp.577-598.

Maurice Archibong (2009).Struggles to breathe life into National Museum Akure after 21year dormancy. Daily Sun. archived from the original on April 11. Retrieved September 2, 2018.

McDonald, R. I., Forman, R. T. and Kareiva, P. (2010). Open space loss and land inequality in United States' cities. 5(3), pp.95-109. 
Miller, R. W. (1997). Urban forestry: Planning and managing urban greenspaces. 2nd ed. Prentice-Hall, Englewood Cliffs, New Jersey. 37(1), pp. 1-18.

Milligan, C., Gatrell, A. and Bingley, A. (2004). Cultivating health: Therapeutic landscapes and older people in Northern England. Social Science \& Medicine, 58(9), pp.17811793.

Ministry of State for Environmental Affairs (MSEA). (2005). Egyptian Environmental Affairs Agency (EEAA), Country Analysis Briefs, Environmental International Agency. Retrieved August 23,2018.

Miyan, R. A. and Rakibul, H. (2003). People's Perception toward Value of Urban Greenspace in Environmental Development. World Forestry Congress, Qubec, Canada. (pp. 1-2).

Mpofu, T. P. Z. (2013). Environmental challenges of urbanisation: A case study for open green space management. Research Journal of Agricultural and Environmental Management, 2(4), pp.105-110.

Muhumuza, M and Balkwill, K. (2013). Factors affecting the success of conserving biodiversity in national parks: A review of case studies from Africa. International Journal of Biodiversity, 10(1), pp.150-155

National Auditor Office (2006). Enhancing Urban Green Space. www.nao.org.uk. Accessed on $16 / 04 / 2020$.

Nowak, D. J., Crane, D. E and Stevens, J. C. (2006). Air pollution removal by urban trees and shrubs in the United States. Urban Forestry \& Urban Greening, 4(3-4), pp.115-123.

Oduwaye, L., (2013). Globalization and urban land use planning: The case of Lagos, Nigeria. A paper presented at the 18th International Conference on Urban Planning, Regional Development and Information Society. Rome, Italy. 11(20), pp.1-21.

Oladeji , S.O and Adedapo , O. O (2014). Performance and Visitor's Satisfaction of Recreation Facilities in Akure Metropolis: A Veritable Tool for Impacts Studies in Undp Mdg's Cities in Nigeria. British Journal of Economics, Management and Trade 4(8), pp.1230-1250.

Passent, T., Nicholas, O., Khaled, G. and Mohamed, A. S. (2009). Green Consciousness of Consumers in a Developing Country: A Study of Egyptian Consumers. Contemporary Management Research, 5, pp. 29-50.

Pope, C.A., Burnett, R.T., Thun, M.J., Calle, E.E., Krewski, D., Ito, K. and Thurston, G.D. (2002). Lung cancer, cardiopulmonary mortality, and long-term exposure to fine particulate air pollution, JAMA.287(9), pp.1132-41.

Sanesi, G. and Chiarello, F. (2006). 'Residents and urban green spaces: the case of Bari', Urban Forestry and Urban Greening, 4, pp.125-134.

Scott, M. M., Cohen, D. A., Evenson, K. R., Elder, J., Catellier, D., Ashwood, J. S. and Overton, A. (2007). Weekend schoolyard accessibility, physical activity, and obesity: The Trial of Activity in Adolescent Girls (TAAG) study. Preventive Medicine, 44, pp. 398-403.

Schiffman, L. G. and Kanuk, L. L. (1987). Consumer Behaviour. Third Edition. New Jersey, Prentice Hall.

Sudarmadi, S., Suzuki, T., Kawada, H., Netti, S., Soemanti; S. and Tritugasawati, A. (2001). A survey of perception, knowledge, awareness and attitude in regard to environmental problems in a sample of two different social groups in Jakarta, Indonesia. Environ. Dev. Sustainability, 3, pp.169-183.

Swanwick, C., Dunnett, N. and Woolley, H. (2003). Nature, role and value of green space in towns and cities: an overview. Built Environment, 29(2), pp. 94-106.

Tan, B.C. and Lau, T.C. (2010). Attitude towards the environment and green products: consumers' perspective. Management Science and Engineering. Vol. 4, No. 2, 2010, pp. 27-39. 
Tanner, R. and Gange, A. C. (2005). Effects of golf courses on local biodiversity. Landscape and Urban Planning. 71(2-4), 137-146.

Takano. T., Nakamura, K. and Watanabe, M. (2002). Urban residential environments and senior citizens' longevity in megacity areas: the importance of walkable green spaces. J Epidemiol Community Health. 56(12), pp.913-8.

Tewari, V. (2019). Seasonality in Tourism: The case of Omman. Journal of Tourism \& Management Research, .4(2), pp.463-476.

Wolch, J. R., Byrne, J. and Newell, J. P. (2014). Urban green space, public health, and environmental justice: The challenge of making cities 'just green enough'. Landscape \& Urban Planning, 125, pp.234-244.

World Health Organization (WHO) (2007). Prevention of cardiovascular disease : guidelines for assessment and management of total cardiovascular risk. WHO Library Cataloguing-in-Publication Data. Retrieved April, 2020 from https://www.who.int/cardiovascular_diseases/guidelines/Full\%20text.pdf.

WHO Regional Office for Europe (2016). Urban green spaces and health: a review of evidence. Copenhagen: WHO Regional Office for Europe (http://www.euro.who.int/ en/health-topics/environment-and-health/urbanhealth/publications/2016/urban-greenspaces-and health-a-review-of-evidence-2016. Retrieved September, 2018.

WHO Regional Office for Europe (2017). Urban green spaces and health: a review of impacts and effectiveness. Copenhagen: WHO Regional Office for Europe. http://www.euro.who.int/pubrequest. Retrieved $29^{\text {th }}$ April, 2020.

Yusof, M. J. M. (2012). The true colours of urban green spaces: Identifying and assessing the qualities of green spaces in Kuala Lumpur, Malaysia. $\mathrm{PhD}$ thesis submitted at the Institute of Geography, School of Geosciences, and University of Edinburgh. 